\title{
Towards a Stepped Care Model for Managing Fear of Cancer Recurrence or Progression in Cancer Survivors
}

\section{Poorva Pradhan (1) \\ Louise Sharpe \\ Rachel E Menzies}

School of Psychology, Faculty of Science, The University of Sydney, Sydney, NSW, 2006, Australia
Correspondence: Louise Sharpe School of Psychology, The University of Sydney, Sydney, NSW, 2006, Australia Tel +6l 93514558

Email louise.sharpe@Sydney.edu.au
Background: Fear of cancer recurrence or progression (FCR) is common amongst cancer survivors and an important minority develop clinically significant levels of FCR. However, it is unclear how current clinical services might best support the growing numbers of cancer survivors. Purpose: The aim of this study is to develop recommendations for future research in the management of FCR and propose a model of care to help manage FCR in the growing population of cancer survivors.

Methods: This is a narrative review and synthesis of empirical research relevant to managing FCR. We reviewed meta-analyses, systematic reviews and individual studies that had investigated interventions for FCR.

Results: A recent, well-conducted meta-analysis confirmed a range of moderately effective treatments for FCR. However, many survivors continued to experience clinical levels of FCR after treatment, indicating a clear need to improve the gold standard treatments. Accessibility of interventions is arguably a greater concern. The majority of FCR treatments require face-to-face therapy, with highly skilled psycho-oncologists to produce moderate changes in FCR. With increasing numbers of cancer survivors, we need to consider how to meet the unmet need of cancer survivors in relation to FCR. Although there have been attempts to develop minimal interventions, these are not yet sufficiently well supported to warrant implementation. Attempts to help clinicians to provide information which might prevent the development of clinically significant FCR have shown some early promise, but research is needed to confirm efficacy.

Conclusion: The next decade of research needs to focus on developing preventative approaches for FCR, and minimal interventions for those with mild-to-moderate symptoms. When evidence-based approaches to prevent FCR or manage moderate levels of FCR are available, stepped care approaches that could meet the needs of survivors could be implemented. However, we also need to improve existing interventions for severe FCR.

Keywords: cancer, oncology, fear of cancer recurrence, fear of progression, FCR interventions

\section{Introduction}

Improved methods for early cancer detection and more effective treatment have significantly decreased cancer mortality rates. ${ }^{1}$ As a result, there is a growing number of cancer survivors who are faced with a wide range of survivorship issues. The most prominent and persistent concern revealed by cancer survivors is the fear of cancer recurrence or progression. ${ }^{2-5}$ According to the recent consensus definition, FCR is the "fear, worry or concern relating to the possibility that cancer will come back or progress". 6 FCR has been identified as one of the most common 
concerns of survivors and help with FCR is amongst the most cited unmet needs of cancer survivors. ${ }^{5}$

Following a cancer diagnosis and its treatment, it is normal and potentially adaptive for survivors to be concerned about the possibility that their cancer may recur. Such concerns can motivate the adoption of a healthy lifestyle, vigilance towards potential signs and symptoms of recurrence and promote adherence to medical follow-up. ${ }^{7,8}$ For this reason, it is unsurprising that FCR is common and research shows that almost $73 \%$ of cancer survivors across different cancers report some degree of FCR. Importantly, nearly half of all survivors (49\%) report a moderate to high degree of concern about FCR with approximately 7\% reporting a severe level of FCR. ${ }^{5}$ Amongst those with moderate to severe concerns, FCR can become chronic and cause a range of negative consequences, even when the risk of recurrence of disease is low. ${ }^{5,9,10}$ Clinically significant levels of FCR are characterized by persistent worry, preoccupation with bodily checking for signs of cancer, and the frequent need for reassurance from hospital services. ${ }^{11,12}$ As a result of reassurance seeking, clinically significant levels of FCR are typically associated with increased health-care costs. ${ }^{13,14}$

In addition to the costs, higher levels of FCR have consistently been associated with increased depressive, anxiety and post-traumatic stress symptoms, ${ }^{15-17}$ as well as the experience of psychiatric disorders. ${ }^{3}$ Since clinical levels of FCR do not appear to dissipate over time, individuals often require specialized psychological support and intervention to manage symptoms of FCR. ${ }^{18}$

A survey conducted in 2014, however, showed that there was little agreement about the best approach to managing FCR. Thewes et $\mathrm{al}^{19}$ conducted a survey amongst 141 oncology health-care workers ( 77 health professionals and 64 psycho-oncologists) about their current approaches to managing FCR. The respondents reported that more than half of the survivors whom they saw in their practice had an issue with FCR. Amongst the health professionals, only $21 \%$ reported referring survivors with FCR to psycho-oncologists. Further, while psychooncologists used a range of interventions to manage FCR, all bar one of the respondents wanted additional training to help manage FCR. Thewes et al ${ }^{19}$ highlighted the need for the development of effective, theoretically driven treatments for FCR and, since the publication of that survey, there have been randomized controlled trials (RCTs) of different approaches for the management of FCR.

\section{Evidence-Based Approaches to FCR}

While FCR has been an outcome in RCTs of psychosocial interventions that generally aim to reduce distress, ${ }^{20-22}$ there have been fewer interventions that have explicitly targeted FCR, as a primary outcome. The earliest approaches used a cognitive behavioural approach, likely due to the fact that the prevailing model of FCR was based on the self-regulation theory. ${ }^{23}$ This model argued that FCR is a multidimensional construct comprised cognitive and emotional components. According to this model, an emotion (eg, fear) results when one misinterprets neutral bodily sensations. That is, it is those individuals who believe that cancer is likely to recur, who become anxious and then behave in ways to reduce the anxiety, such as checking or avoiding hospital appointments, which leads to increased fear responses over time. However, these approaches had modest success. For example, Herschbach et $\mathrm{al}^{24}$ found that CBT was more effective than a (non-randomized) no treatment control group, but not a non-directive supportive control group. Similarly, the AFTER intervention ${ }^{25}$ showed some evidence of improvement in FCR following treatment in oral cancer patients, but the median number of sessions attended was two, indicating less than ideal attendance. However, with a proliferation of new theoretical models (eg, cognitive processing $\operatorname{model}^{7}$ ), so too followed a number of interventions based on those theories (eg, ConquerFear ${ }^{26}$ ).

In the most comprehensive meta-analysis to date, Tauber et $\mathrm{al}^{27}$ evaluated 23 controlled trials ( 21 of them were randomised controlled trials) of a psychological intervention where FCR was measured as an outcome. Their results confirmed that psychological treatments are effective for FCR; however, the effect is small (Hedge's $\mathrm{g}=0.33)$. The quality of the evidence overall led the authors to be moderately confident of the estimate of their effect size using the GRADE criteria.

Tauber et $\mathrm{al}^{27}$ also examined a range of moderators, including type of therapy (contemporary or traditional CBT), cancer type, FCR as primary or secondary target, intervention format (group or individual) and delivery (face to face or other). The type of therapy did give rise to different treatment effects. Specifically, Tauber et $\mathrm{al}^{27}$ categorised interventions into traditional CBT which focused on challenging beliefs and changing behaviours (10 interventions) and contemporary CBT which focused on cognitive processes and encourages people to accept negative beliefs and emotions based on more recent 
theoretical views of FCR (9 interventions). The results showed a difference between traditional and contemporary CBTs that favoured contemporary CBT (Hedge's $g=0.42$ ) as compared to traditional CBTs (Hedge's $\mathrm{g}=0.24$ ). However, these benefits were only observed at posttreatment. Interestingly, only 8 of the interventions included in the meta-analysis included FCR as a primary outcome. It is also worthwhile noting that majority of the FCR-specific interventions were face to face (for example, ConquerFear, ${ }^{26} \mathrm{CBT}^{24}$ ) or adopted a blended approach that is combined online with face to face (eg, van de Wal et $\mathrm{al}^{28}$ ). The 19 face-to-face interventions in the Tauber et $\mathrm{al}^{27}$ meta-analysis involved between 1 and 15 sessions, with a median of 6 sessions. Further, interventions that were not face-to-face, did not result in significant change in total FCR when considered alone. Hence, the results of this meta-analysis suggest that even reasonably intensive interventions that are administered by highly trained psycho-oncology professionals give rise to modest effects. Further, a number of gaps were evident in the literature, more than half of the included trials were in early-stage breast cancer treated with curative intent, and the majority of trials were with survivors who were currently disease free. Given the recent efficacy of novel interventions including immunotherapies and personalised medicine that are leading survivors to live long lives with disease in many cases (see Thewes et al $^{29}$ ), we need more trials in other cancer types, particularly those with advanced disease.

While Tauber et al's ${ }^{27}$ meta-analysis confirmed the efficacy of available interventions, it also highlighted a number of important limitations to the literature. Given the estimated and growing unmet need for management of FCR, it will be impossible to implement the intensive faceto-face approaches with established efficacy to all participants with moderate to severe FCR. Instead, there is a need to develop a model of care where we stratify care to the level of severity with increasingly intensive interventions reserved for those with the most serious or severe difficulties. However, to have an optimal stepped care model, we need to (a) prevent the development of clinically significant levels of FCR, where possible; (b) develop effective minimal interventions for FCR; (c) upskill non psychology health-care professionals in managing FCR; and (d) develop more efficacious treatments for a greater range of survivors. See Table 1 for a detailed account of these studies.

\section{Can Clinically Significant Levels of FCR Be Prevented?}

Most models of FCR identify that a survivor's knowledge of the realistic likelihood of recurrence and likely signs of recurrence contribute to clinically significant levels of FCR. ${ }^{7,23}$ That is, a lack of information about prognosis and signs of recurrence increases the likelihood that people will experience a clinically significant level of FCR. As such, it is possible that good doctor-patient communication about these topics at the end of treatment may help reduce the chance of developing clinically significant levels of FCR. Butow et al ${ }^{18}$ recommended that all members of the oncology team should consider FCR to be a topic of relevance to their care of the patient.

The literature on potential preventative programs is in its infancy. A systematic review by Liu et $\mathrm{al}^{30}$ identified only five trials of non-psychologist delivered (four of them were nurse led) communication. Only three of the trials had a control arm (the remainder were Phase I pilot interventions), hence these trials were at a high risk of bias. One intervention (the AFTER intervention: Adjustment to the Fears, Threat and Expectation of Recurrence ${ }^{25}$ ) consisted of 6 weekly sessions with a nurse. This intervention comprised CBT, relaxation and patient-centred approach and reduced FCR levels at post-intervention, but not follow-up. The second trial was a single-session nurse-led coaching intervention, where nurses coached survivors to communicate more with their oncology team about recurrence. ${ }^{31}$ Although participants were satisfied with the intervention, there were no impacts on FCR. However, the study had only 44 participants and so was likely under-powered. According to Liu et al, ${ }^{30}$ some approaches have shown feasibility and a lack of harm in early trials. The most common strategies were allowing participants to discuss their fears, and providing reassurance and normalisation. More recently, Liu et $\mathrm{al}^{32}$ also conducted a single-arm study of an oncology delivered intervention that normalised FCR, provided personal prognostic information, educated survivors about symptoms of recurrence and gave advice about managing FCR worries and information about referral, where necessary. This intervention was only 8 minutes long, on average, which was considered to be feasible. FCR did improve over the trial, although whether this is as a result of the intervention is unclear. As such, there remains insufficient data to recommend widespread adoption of these approaches. 
Table I Study Characteristics and Results of Included Papers

\begin{tabular}{|c|c|c|c|c|c|c|c|}
\hline & \multirow{2}{*}{$\begin{array}{l}\text { Sample } \\
\text { Size }\end{array}$} & \multirow{2}{*}{$\begin{array}{l}\text { Type of } \\
\text { Cancer }\end{array}$} & \multirow{2}{*}{$\begin{array}{l}\text { No. } \\
\text { of } \\
\text { Arms }\end{array}$} & \multirow[t]{2}{*}{ Delivery Mode } & \multirow[t]{2}{*}{ Intervention } & \multirow[t]{2}{*}{ Outcomes } & \multirow{2}{*}{$\begin{array}{l}\text { Effect Size } \\
\text { Cohen's d (Time of } \\
\text { Assessment) }\end{array}$} \\
\hline & & & & & & & \\
\hline \multicolumn{7}{|c|}{ I.Psychoeducation and preventative interventions } & \\
\hline \multirow{2}{*}{$\begin{array}{l}\text { Pradhan et al } \\
(2021)^{38}\end{array}$} & \multirow[t]{2}{*}{62} & \multirow{2}{*}{$\begin{array}{l}\text { Ovarian } \\
\text { Cancer }\end{array}$} & \multirow{2}{*}{$\begin{array}{l}\text { Single- } \\
\text { arm }\end{array}$} & \multirow{2}{*}{$\begin{array}{l}\text { Online: } \\
\text { Psychoeducational } \\
\text { booklet }\end{array}$} & \multirow{2}{*}{$\begin{array}{l}\text { Psychoeducation: Online PDF } \\
\text { booklet. }\end{array}$} & \multirow{2}{*}{$\begin{array}{l}\text { No effect on fear of } \\
\text { progression }\end{array}$} & 0.17 \\
\hline & & & & & & & I week \\
\hline \multirow{2}{*}{$\begin{array}{l}\text { Liu et al } \\
(2021)^{32}\end{array}$} & \multirow[t]{2}{*}{61} & \multirow[t]{2}{*}{ Breast Cancer } & \multirow{2}{*}{$\begin{array}{l}\text { Single- } \\
\text { arm }\end{array}$} & \multirow[t]{2}{*}{ Face-to-face } & \multirow{2}{*}{$\begin{array}{l}\text { Oncologist delivered preventative } \\
\text { intervention }\end{array}$} & \multirow[t]{2}{*}{ FCR reduced } & 0.39 (1 month) \\
\hline & & & & & & & 0.68 (3 months) \\
\hline \multirow{3}{*}{$\begin{array}{l}\text { Dieng et al } \\
(2016)^{40}\end{array}$} & \multirow[t]{3}{*}{164} & \multirow[t]{3}{*}{ Melanoma } & \multirow[t]{3}{*}{ Two } & \multirow{2}{*}{$\begin{array}{l}\text { Psychoeducational } \\
\text { booklet }\end{array}$} & \multirow{3}{*}{$\begin{array}{l}\text { Psychoeducation plus } \\
\text { psychodynamic-based } \\
\text { psychotherapy }\end{array}$} & \multirow[t]{3}{*}{ FCR reduced } & 0.5 (I month) \\
\hline & & & & & & & \multirow[t]{2}{*}{0.3 (6 months) } \\
\hline & & & & $\begin{array}{l}3 \text { Telephone } \\
\text { sessions }\end{array}$ & & & \\
\hline $\begin{array}{l}\text { Sterba et al } \\
(2015)^{83}\end{array}$ & 92 & Breast Cancer & Two & Mixed & $\begin{array}{l}\text { In-person video sessions and } \\
\text { educational booklets }\end{array}$ & $\begin{array}{l}\text { No effect on cancer- } \\
\text { related worries }\end{array}$ & -0.22 \\
\hline \multicolumn{7}{|c|}{ II.Self-help and internet-delivered interventions } & \\
\hline Otto et al & 67 & Breast Cancer & Two & Online & Positive psychology: Gratitude & No effect on FCR & 0.21 (1 month) \\
\hline$(2017)^{42}$ & & & & & intervention & & 0.1 (3 months) \\
\hline Lichtenthal & 110 & Breast Cancer & Two & Online & Cognitive Bias Modification & No effect of Cancer & 0.35 \\
\hline et al (2017) & & & & & (Interpretation and Attention) & Worry Scale & Post-treatment \\
\hline & & & & & & & 0.54 (3 months) \\
\hline $\begin{array}{l}\text { van Helmondt } \\
\text { et al, }(2020)^{49}\end{array}$ & 262 & Breast Cancer & Two & Online & Cognitive behaviour therapy & No effect on FCR & Not reported \\
\hline Omidi et al & 105 & Breast Cancer & Three & Face to face & Group and social network-based & No effect on FCR & Group education: 0.21 \\
\hline$(2020)^{37}$ & & & & Online & $\begin{array}{l}\text { self-management education on } \\
\text { lymphedema }\end{array}$ & & $\begin{array}{l}\text { Social Network-based } \\
\text { education: } 0.06 \text { ( } 3 \text { months) }\end{array}$ \\
\hline Dirkse et al & 86 & Multiple & Two & Face to face & Cognitive behaviour therapy & Reduction in FCR & $0.93-0.85$ (I month) \\
\hline (2019) & & & & Online & & & \\
\hline $\begin{array}{l}\text { Lengacher } \\
\text { et al }(2018)^{76}\end{array}$ & 15 & Breast Cancer & $\begin{array}{l}\text { Single- } \\
\text { arm }\end{array}$ & Online & $\begin{array}{l}\text { Mobile-based Mindfulness Stress } \\
\text { Reduction for Breast Cancer }\end{array}$ & $\begin{array}{l}\text { Improvements in fear of } \\
\text { recurrence at } 6 \text { weeks } \\
\text { follow-up }\end{array}$ & 0.74 \\
\hline $\begin{array}{l}\text { Germino et al } \\
(2012)^{71}\end{array}$ & 313 & Breast Cancer & Two & Self-directed & Traditional CBT & $\begin{array}{l}\text { No significant } \\
\text { improvement in FCR was } \\
\text { reported. }\end{array}$ & Not reported \\
\hline III.Health-car & professio & Is led intervent & & & & & \\
\hline $\begin{array}{l}\text { Humphris \& } \\
\text { Rogers } \\
(2012)^{25}\end{array}$ & 90 & Head and Neck & Two & $\begin{array}{l}\text { Face to face, } \\
\text { nurse-led }\end{array}$ & Cognitive behavioural therapy & $\begin{array}{l}\text { FCR reduced during } \\
\text { treatment, improvement } \\
\text { not maintained }\end{array}$ & 0.56 (3 months) \\
\hline $\begin{array}{l}\text { Shields et al } \\
(2010)^{31}\end{array}$ & 44 & Breast Cancer & Two & $\begin{array}{l}\text { Single session, } \\
\text { tele-coaching }\end{array}$ & $\begin{array}{l}\text { Encourage patients to raise top } 3 \\
\text { concerns with oncologist }\end{array}$ & No effect on FCR & -0.13 \\
\hline Reb et al & 31 & Gynaecology & Single- & In person and & Contemporary $\mathrm{CBT}$, hybrid online & Reduction in FoP at 8 and & 1.3 (8 weeks) \\
\hline$(2020 b)^{34}$ & & Lung Cancer & arm & online & and face-to-face & $\begin{array}{l}12 \text { weeks after } \\
\text { intervention. }\end{array}$ & \\
\hline
\end{tabular}

(Continued) 
Table I (Continued).

\begin{tabular}{|c|c|c|c|c|c|c|c|}
\hline & \multirow{2}{*}{$\begin{array}{l}\text { Sample } \\
\text { Size }\end{array}$} & \multirow{2}{*}{$\begin{array}{l}\text { Type of } \\
\text { Cancer }\end{array}$} & \multirow{2}{*}{$\begin{array}{l}\text { No. } \\
\text { of } \\
\text { Arms }\end{array}$} & \multirow[t]{2}{*}{ Delivery Mode } & \multirow[t]{2}{*}{ Intervention } & \multirow[t]{2}{*}{ Outcomes } & \multirow{2}{*}{$\begin{array}{l}\text { Effect Size } \\
\text { Cohen's d (Time of } \\
\text { Assessment) }\end{array}$} \\
\hline & & & & & & & \\
\hline \multicolumn{8}{|c|}{ IV.Intensive specialist care } \\
\hline \multirow[t]{2}{*}{$\begin{array}{l}\text { Herschbach } \\
\text { et al }(2010)^{24}\end{array}$} & \multirow[t]{2}{*}{265} & \multirow[t]{2}{*}{ Multiple } & \multirow[t]{2}{*}{ Three } & \multirow[t]{2}{*}{ Face to face } & \multirow[t]{2}{*}{$\begin{array}{l}\text { CBT and SET (based on personal } \\
\text { experiences) }\end{array}$} & \multirow{2}{*}{$\begin{array}{l}\text { Reduction in FoP scores } \\
\text { after } 12 \text { months for both } \\
\text { intervention groups. }\end{array}$} & $\begin{array}{l}\text { CBT: } \\
0.61\end{array}$ \\
\hline & & & & & & & $\begin{array}{l}\text { SET: } \\
0.56 \text { (12 months) }\end{array}$ \\
\hline \multirow{2}{*}{$\begin{array}{l}\text { Butow et al } \\
(2017)^{26}\end{array}$} & \multirow[t]{2}{*}{222} & \multirow[t]{2}{*}{ Multiple } & \multirow[t]{2}{*}{ Two } & \multirow[t]{2}{*}{ Face to face } & \multirow{2}{*}{$\begin{array}{l}\text { Contemporary } \mathrm{CBT} \text { and } \\
\text { relaxation training }\end{array}$} & \multirow{2}{*}{$\begin{array}{l}\text { Improvements in both } \\
\text { total FCR-I and severity } \\
\text { subscale }\end{array}$} & 0.33 (3 months) \\
\hline & & & & & & & 0.39 (6 months) \\
\hline $\begin{array}{l}\text { Van de Wal } \\
\text { et al }(2017)^{28}\end{array}$ & 88 & Multiple & Two & $\begin{array}{l}\text { Mixed: } \\
\text { Face-to-face and } \\
\text { online sessions }\end{array}$ & $\begin{array}{l}\text { Blended cognitive behaviour } \\
\text { therapy }\end{array}$ & $\begin{array}{l}\text { Improvements in FCR at } \\
3 \text { months post } \\
\text { intervention. }\end{array}$ & 0.76 \\
\hline $\begin{array}{l}\text { Bannaasan } \\
\text { et al }(2015)^{64}\end{array}$ & 59 & Breast Cancer & Two & Face-to-face & Buddhist doctrine-based practice & $\begin{array}{l}\text { Reduction in FCR scores } \\
\text { after I month. }\end{array}$ & 1.38 (I month) \\
\hline $\begin{array}{l}\text { Tomei et al } \\
(2018)^{84}\end{array}$ & 25 & Multiple & Two & Face to face & Traditional CBT & $\begin{array}{l}\text { Reduction in FCR at } \\
\text { post-intervention }\end{array}$ & 0.28 \\
\hline $\begin{array}{l}\text { Cameron } \\
\text { et al }(2007)^{66}\end{array}$ & 154 & Breast Cancer & Two & Face to face & $\begin{array}{l}\text { Contemporary CBT for emotional } \\
\text { regulation and adjustment }\end{array}$ & $\begin{array}{l}\text { Decrease in cancer } \\
\text { recurrence worries after } \\
4 \text { months, not maintained } \\
\text { after } 6 \text { and } 12 \text { months. }\end{array}$ & 0.59 \\
\hline $\begin{array}{l}\text { Lengacher } \\
\text { et al }(2009)^{22}\end{array}$ & 84 & Breast Cancer & Two & Face to face & $\begin{array}{l}\text { Mindfulness-based stress } \\
\text { reduction }\end{array}$ & $\begin{array}{l}\text { Improvement in FCR } \\
\text { after } 6 \text { weeks. }\end{array}$ & 0.6 \\
\hline $\begin{array}{l}\text { Crane-Okada } \\
\text { et al }(2012)^{68}\end{array}$ & 49 & Breast Cancer & Two & Face to face & $\begin{array}{l}\text { Mindful movement program } \\
\text { intervention }\end{array}$ & $\begin{array}{l}\text { Decrease in FCR at } 6 \\
\text { weeks }\end{array}$ & 0.57 \\
\hline $\begin{array}{l}\text { Heinrichs } \\
\text { et al }(2012)^{22}\end{array}$ & 72 & $\begin{array}{l}\text { Breast and } \\
\text { Gynaecological } \\
\text { cancer }\end{array}$ & Two & Face to face & Couple based coping intervention & $\begin{array}{l}\text { Decrease in FoP for } \\
\text { intervention participants }\end{array}$ & 0.57 \\
\hline $\begin{array}{l}\text { Bower et al } \\
(2015)^{65}\end{array}$ & 71 & Breast Cancer & Two & Face to face & Mindfulness-based intervention & $\begin{array}{l}\text { Improvements in FCR at } \\
3 \text { month follow-up in } \\
\text { intervention group }\end{array}$ & 1.39 \\
\hline $\begin{array}{l}\text { Dodds et al } \\
(2015)^{70}\end{array}$ & 33 & Breast Cancer & Two & Face to face & $\begin{array}{l}\text { Meditation-based program called } \\
\mathrm{CBCT}\end{array}$ & $\begin{array}{l}\text { Reduction in FCR in } \\
\text { intervention group }\end{array}$ & -1.38 \\
\hline \multirow{2}{*}{$\begin{array}{l}\text { Lengacher } \\
\text { et al }(2016)^{75}\end{array}$} & \multirow[t]{2}{*}{322} & \multirow[t]{2}{*}{ Breast Cancer } & \multirow[t]{2}{*}{ Two } & \multirow[t]{2}{*}{ Face to face } & \multirow{2}{*}{$\begin{array}{l}\text { Mindfulness-Based Stress } \\
\text { Reduction for Breast Cancer }\end{array}$} & \multirow{2}{*}{$\begin{array}{l}\text { Improvements in FCR at } \\
6 \text { and } 12 \text { week follow-up }\end{array}$} & 0.3 (6 weeks) \\
\hline & & & & & & & 0.28 (12 weeks) \\
\hline $\begin{array}{l}\text { Merckaert } \\
\text { et al }(2016)^{78}\end{array}$ & 159 & Breast Cancer & Two & Face to face & CBT and hypnosis & $\begin{array}{l}\text { Reduction in FCR } \\
\text { severity post } \\
\text { intervention }\end{array}$ & 0.33 \\
\hline $\begin{array}{l}\text { Manne et al } \\
(2017)^{77}\end{array}$ & 352 & $\begin{array}{l}\text { Gynaecological } \\
\text { Cancer }\end{array}$ & Three & $\begin{array}{l}\text { Face to face and I } \\
\text { telephone session }\end{array}$ & $\begin{array}{l}\text { Communication-enhancing } \\
\text { intervention }(\mathrm{CCl}) \text { and supportive } \\
\text { counselling }(\mathrm{SC})\end{array}$ & No effect on FCR & 0.11 \\
\hline $\begin{array}{l}\text { Victorson } \\
\text { et al }(2016)^{85}\end{array}$ & 43 & Prostate & Two & Face to face & $\begin{array}{l}\text { Mindfulness Based Stress } \\
\text { Reduction }\end{array}$ & $\begin{array}{l}\text { Reduction in recurrence } \\
\text { fears }\end{array}$ & 0.15 \\
\hline
\end{tabular}

(Continued) 
Table I (Continued).

\begin{tabular}{|c|c|c|c|c|c|c|c|}
\hline & \multirow{2}{*}{$\begin{array}{l}\text { Sample } \\
\text { Size }\end{array}$} & \multirow{2}{*}{$\begin{array}{l}\text { Type of } \\
\text { Cancer }\end{array}$} & \multirow{2}{*}{$\begin{array}{l}\text { No. } \\
\text { of } \\
\text { Arms }\end{array}$} & \multirow[t]{2}{*}{ Delivery Mode } & \multirow[t]{2}{*}{ Intervention } & \multirow[t]{2}{*}{ Outcomes } & Effect Size \\
\hline & & & & & & & $\begin{array}{l}\text { Cohen's d (Time of } \\
\text { Assessment) }\end{array}$ \\
\hline \multirow{2}{*}{$\begin{array}{l}\text { Gonzalez- } \\
\text { Hernandez } \\
\text { et al }(2018)^{72}\end{array}$} & \multirow[t]{2}{*}{56} & \multirow[t]{2}{*}{ Breast Cancer } & \multirow[t]{2}{*}{ Two } & \multirow[t]{2}{*}{ Face to face } & \multirow[t]{2}{*}{ Compassion-based intervention } & \multirow{2}{*}{$\begin{array}{l}\text { Reduction in FCR related } \\
\text { stress at post- } \\
\text { intervention and } 6 \text { mth } \\
\text { follow-up }\end{array}$} & 0.68 (post-intervention) \\
\hline & & & & & & & 0.46 (6 months) \\
\hline $\begin{array}{l}\text { Chambers } \\
\text { et al }(2012)^{67}\end{array}$ & 19 & Prostate & $\begin{array}{l}\text { Single- } \\
\text { arm }\end{array}$ & Face to face & $\begin{array}{l}\text { Mindfulness-based cognitive } \\
\text { therapy group intervention }\end{array}$ & Reduction in FCR & 0.28 \\
\hline $\begin{array}{l}\text { Lebel et al } \\
(2014)^{74}\end{array}$ & 56 & $\begin{array}{l}\text { Breast and } \\
\text { ovarian cancer }\end{array}$ & $\begin{array}{l}\text { Single- } \\
\text { arm }\end{array}$ & Face to face & $\begin{array}{l}\text { Cognitive-existential (CE) group } \\
\text { intervention }\end{array}$ & Reduction in FCR & 0.73 \\
\hline $\begin{array}{l}\text { Seitz et al } \\
(2014)^{81}\end{array}$ & 20 & $\begin{array}{l}\text { Multiple } \\
\text { cancers }\end{array}$ & $\begin{array}{l}\text { Single- } \\
\text { arm }\end{array}$ & Online & Traditional CBT & Decrease in FoP & 0.48 \\
\hline \multirow[t]{2}{*}{$\begin{array}{l}\text { Smith et al } \\
(2015)^{82}\end{array}$} & \multirow[t]{2}{*}{8} & \multirow[t]{2}{*}{$\begin{array}{l}\text { Multiple } \\
\text { cancers }\end{array}$} & \multirow[t]{2}{*}{$\begin{array}{l}\text { Single- } \\
\text { arm }\end{array}$} & \multirow[t]{2}{*}{ Face to face } & \multirow[t]{2}{*}{ Contemporary CBT } & \multirow{2}{*}{$\begin{array}{l}\text { Reduction in overall FCR } \\
\text { scores and severity } \\
\text { subscale at 2-month } \\
\text { follow-up }\end{array}$} & $\begin{array}{l}\text { FCR Severity: } \\
1.9\end{array}$ \\
\hline & & & & & & & $\begin{array}{l}\text { FCRI-Total: } \\
1.8\end{array}$ \\
\hline \multirow{2}{*}{$\begin{array}{l}\text { Arch \& } \\
\text { Mitchell } \\
(2015)^{63}\end{array}$} & \multirow[t]{2}{*}{42} & \multirow{2}{*}{$\begin{array}{l}\text { Multiple } \\
\text { cancers }\end{array}$} & \multirow{2}{*}{$\begin{array}{l}\text { Single- } \\
\text { arm }\end{array}$} & \multirow[t]{2}{*}{ Face to face } & \multirow[t]{2}{*}{$\mathrm{ACT}$} & \multirow{2}{*}{$\begin{array}{l}\text { FCR decreased at post } \\
\text { intervention, but I mth } \\
\text { follow-up }\end{array}$} & 0.66 (post-treatment) \\
\hline & & & & & & & 0.11 (1 month) \\
\hline \multirow{2}{*}{$\begin{array}{l}\text { Momino et al } \\
(2017)^{79}\end{array}$} & \multirow[t]{2}{*}{40} & \multirow[t]{2}{*}{ Breast } & \multirow{2}{*}{$\begin{array}{l}\text { Single- } \\
\text { arm }\end{array}$} & Face to face & \multirow{2}{*}{$\begin{array}{l}\text { Collaborative care and need- } \\
\text { based intervention }\end{array}$} & \multirow[t]{2}{*}{ No effect on FCR } & \multirow[t]{2}{*}{0.15} \\
\hline & & & & Telephone sessions & & & \\
\hline $\begin{array}{l}\text { Savard et al } \\
(2018)^{80}\end{array}$ & 33 & $\begin{array}{l}\text { Multiple } \\
\text { cancers }\end{array}$ & $\begin{array}{l}\text { Single- } \\
\text { arm }\end{array}$ & Face to face & Group-based CBT & $\begin{array}{l}\text { Significant decrease in } \\
\text { FCR at post-treatment }\end{array}$ & Not reported \\
\hline $\begin{array}{l}\text { Davidson et al } \\
(2018)^{69}\end{array}$ & 16 & Breast Cancer & $\begin{array}{l}\text { Single- } \\
\text { arm }\end{array}$ & $\begin{array}{l}\text { Telephonic } \\
\text { sessions }\end{array}$ & Intervention based on CBT & $\begin{array}{l}\text { Decrease in FCR after I } \\
\text { week follow-up }\end{array}$ & 0.8 \\
\hline $\begin{array}{l}\text { Johns et al } \\
(2019)^{73}\end{array}$ & 91 & Breast Cancer & Three & Face to face & $\begin{array}{l}\text { Group-based ACT and } \\
\text { Survivorship education }\end{array}$ & $\begin{array}{l}\text { Significant decrease in } \\
\text { FCR severity in ACT } \\
\text { group }\end{array}$ & 0.61 (6 months) \\
\hline Stepped care & & & & & & & \\
\hline $\begin{array}{l}\text { Lynch et al } \\
(2020)^{56}\end{array}$ & 61 & Melanoma & $\begin{array}{l}\text { Single- } \\
\text { arm }\end{array}$ & Mixed & $\begin{array}{l}\text { Three step intervention: (1) } \\
\text { Treatment as usual; (2) Self- }\end{array}$ & $\begin{array}{l}\text { Contemporary CBT } \\
\text { reduced FCR and FoP. }\end{array}$ & $\begin{array}{l}\text { Self-management } \\
-0.11 \text { for FCR }\end{array}$ \\
\hline & & & & & Individual therapy: contemporary & & 0.02 for FoP \\
\hline & & & & & CBT. & & Individual therapy \\
\hline & & & & & & & $0.64 \mathrm{FCR}$ \\
\hline & & & & & & & $0.4 \mathrm{FOP}$ \\
\hline
\end{tabular}

Abbreviations: ACT, Acceptance and Commitment Therapy; AFTER, adjustment to the fear expectation or threat of recurrence; bCBT, blended cognitive behavioural therapy; CAREST, cancer recurrence self-help training; CAU, care as usual; CBT, cognitive-behavioral group therapy; CBCT, Cognitively-Based Compassion training; FCR, fear of cancer recurrence; FoP, fear of progression; MCT, meta-cognitive therapy; SET, supportive-experiential therapy; S-REF, Self-Regulation of Executive Function. 


\section{Up-Skilling Health Professionals to Deliver Psychosocial Interventions}

Whilst the systematic review of Liu et $\mathrm{al}^{30}$ confirmed that it was premature to confirm the efficacy of clinician-based interventions designed to prevent FCR, there were some indications that nurse-delivered interventions could be efficacious. As described previously, Humphris \& Rogers $^{25}$ trained nurses to administer a CBT-based intervention to reduce FCR amongst head and neck cancer patients. There was evidence for efficacy of this intervention compared to a control in the short-term, showing strong proof of concept that nurses can be trained to use CBT to help survivors manage FCR. In a similar vein, researchers have attempted to adapt the ConquerFear program as a nurse-led intervention. ${ }^{33}$ The ConquerFear program was based on Fardell et al's ${ }^{7}$ model of FCR and combined components of acceptance commitment therapy, meta-cognitive therapy and behavioural strategies based on self-regulation theory. The ConquerFear program was used with patients with early-stage breast or colorectal cancer or melanoma, who had been treated with curative intent and were in the clinical range on FCR Inventory. ${ }^{26}$ In a phase I trial, in 33 survivors with advanced lung or gynaecological cancer, Reb et $\mathrm{al}^{34}$ found significant improvements in fear of progression for 21 participants who completed the ConquerFear program in a mixed (zoom/face to face) approach. As an uncontrolled trial, this study was at a high risk of bias; however, the effect sizes that were achieved when ConquerFear was adapted to more advanced disease and administered by nurses were roughly similar to those achieved in the ConquerFear arm in the original study, which is extremely encouraging. ${ }^{34}$ There is considerable evidence that patients show a preference for receiving supportive care from nurses, in comparison to psychologists or psychiatrists, ${ }^{35}$ however, it is only recently that psychological interventions for FCR have been nurse-led. Given the larger nursing workforce in comparison to the psycho-oncology workforce, the ability of nurses to achieve similar outcomes could begin to bridge the gap between effective treatments being available and accessible. Although given the number of survivors, making help with FCR available to all survivors for whom this is an issue will likely require effective minimal interventions.

\section{Minimal Interventions}

Minimal intervention is an umbrella term for interventions that do not require large amounts of therapist time and are typically delivered remotely (eg, telephone, online, a booklet), which allows these interventions to be scalable for a very common problem, where the available workforce cannot meet the needs of the population. These interventions require less time commitment, expertise and resources to achieve an improvement in a particular outcome. ${ }^{36}$ FCR amongst cancer survivors can be seen as an area in which minimal interventions may be necessary to ensure that help with FCR does not remain the leading unmet survivorship needs.

The most minimal of interventions are self-help materials, such as pamphlets, information sheets and online resources. While many cancer organisations internationally have developed their own FCR resources to provide some information and support around FCR/P, these have rarely been evaluated. The efficacy of self-help resources in general was extensively evaluated in a systematic review by Cuthbert et al, ${ }^{37}$ which included 41 randomised trials with psychoeducational self-help component for cancer survivors. The results of this review were mixed across studies, indicating that while some self-help approaches can produce positive outcomes, many fail to and some even produce unintended negative impacts. However, none of the 41 included trials targeted FCR. Only recently has there been research evaluating the efficacy of brief online FCR resources. In one study, an online self-help pamphlet was developed by Ovarian Cancer Australia and its effect on FCR was evaluated. The pamphlet provided information about FCR and suggested strategies to better manage FCR. ${ }^{38}$ These results were consistent with another RCT conducted of information provided either via social media or in group face to face. Omidi et $\mathrm{al}^{39}$ found that there was a significant impact of group education (but not social media information) on quality of life, compared to a control group. However, the provision of information did not have an impact on FCR. As such, it seems unlikely that the provision of simple information will be sufficient to meet the needs of survivors with elevated FCR levels.

In the Tauber et $\mathrm{al}^{27}$ meta-analysis, there were only three minimal interventions that were included. For example, an intervention by Dieng et $\mathrm{al}^{40}$ consisted of a psychoeducational pamphlet and three 15-minute telephone-based psychotherapy sessions by a psychodynamic therapist. It was concluded that this blended intervention 
was effective in improving the levels FCR in early-stage melanoma survivors. These results were maintained at a 12-month follow-up. ${ }^{41}$ The telephone sessions in this intervention, however, require specialist skills. It is, however, unclear whether the self-help resources would be efficacious without that input. The intervention by Otto et $\mathrm{al}^{42}$ involved an online self-directed gratitude training on overall FCR and death-related FCR. The intervention produced an improvement in reducing death-related FCR and promoting well-being in the gratitude intervention group, but there was no impact on FCR total severity. Similarly, Lichtenthal et $\mathrm{al}^{43}$ used a novel Cognitive Bias Modification (CBM) to reduce FCR amongst 120 women with early-stage breast cancer compared to a placebo. CBM is a novel approach which directly aimed to modify implicit cognitive processing biases such as attention or interpretation. ${ }^{44}$ The intervention consisted of 8 personalised treatment sessions that were computerized over the span of 4 weeks. Their intervention was successful in modifying interpretation bias and produced an improvement in the health worries subscale of concerns about recurrence scale as compared to a placebo group. However, the total score for worries about cancer was not significantly improved compared to the placebo group. Therefore, while these approaches showed some promise, more research is definitely needed.

Despite the proliferation of internet-delivered interventions in other areas of psychology, ${ }^{45-48}$ the FCR literature has been somewhat slow to develop and evaluate online versions of the face to face interventions. For instance, Van de Wal et al.'s ${ }^{28}$ SWORD study ("Survivors' Worries of Recurrent Disease") also known as blended cognitive behavioural therapy (bCBT) or partly online. Participants in the intervention condition received 5 individual face to face sessions in combination with three e-consultations. The intervention successfully reduced the severity of FCR on Cancer Worry Scale as compared to control group. SWORD does, of course, have evidence for efficacy suggesting that at least part of the intervention could be offered online. However, stand-alone internet delivered interventions thus far have failed to show clear evidence of efficacy. The only one to be evaluated in an RCT so far is CAREST. ${ }^{49}$ CAREST was a carefully developed intervention based on psychoeducation and CBT principles for FCR. The trial was relatively large $(n=262)$, but failed to show any difference between women who received CAREST or treatment as usual. This was despite reasonable completion rates: $83 \%$ at post-treatment and $70 \%$ at follow-up. This trial therefore questions whether an unsupported, stand-alone intervention will be efficacious when delivered online.

There are, however, a number of other internet-delivered interventions that have been developed. For example, iConquerFear has been co-designed by adapting ConquerFear to an online platform. ${ }^{50}$ It is currently being evaluated. ${ }^{51}$ Akechi et $\mathrm{al}^{52}$ have developed a smartphone intervention, in the SMILE trial, which is currently underway and will deliver a combination of problem-solving therapy and behavioural activation in an attempt to lessen FCR/P. Finally, the FORTitude study ${ }^{53}$ developed an eHealth intervention based on treatments for anxiety disorders but applied to FCR/P. The three active strategies included in the program were relaxation, cognitive restructuring and scheduled worry time. The trial was designed to be able to comment on the relative efficacy of each of these strategies, however, to date the results have not been published. Interesting, a recent study has compared a generic online treatment (Wellbeing after cancer) with and without support and included FCR as an outcome. Dirkse et $\mathrm{al}^{54}$ found that there was a moderate sized effect for reducing FCR of this program, even without support, which shows that internet-delivered interventions have the capacity to be efficacious for FCR.

\section{Stepped-Care Approaches}

There are over 2 million cancer survivors currently living in Australia alone [AIHW, 2020]. Nearly half of all survivors will have moderate levels of $\mathrm{FCR}^{5}$ and in some groups (such as young women with breast cancer), up to $79 \%$ have clinically significant levels of FCR. ${ }^{13}$ Without specific effective minimal interventions, there will be no realistic way in which to meet the needs of cancer survivors to manage FCR. Most oncology services have limited resources to support all survivors with elevated FCR, and thus there seems to be an urgent need to develop evidencebased approaches with different levels of intervention. Although stepped care is often described as any model of service provision with different levels of care, there are three main models for how to determine the flow of patients through services. ${ }^{55}$ True "stepped care" approaches propose that a simple, inexpensive intervention be tried first for all survivors. If the survivor continues to have clinically significant levels of FCR, then a more complex intervention is tried, and so the process continues as the steps become more complex. The second model is stratified care. These approaches tailor FCR interventions, based on the severity of FCR or other known risk factors 
for poor prognosis. Those survivors deemed to have mild, but still bothersome, levels of FCR are referred to minimal interventions, such that more intensive interventions (requiring high professional skills) are reserved for people with clinical FCR who are unlikely to benefit from minimal interventions. The final type of stepped care approach is matched care. Matched care, like stratified care, assesses survivors at baseline, and determines not only the intensity of intervention, but also the nature of intervention based upon different presenting risk factors.

To date, there has been a single stepped care approach described in the literature, the 'FearLESS' program. $^{56}$ FearLESS was developed for advanced melanoma survivors who had responded to immunotherapies, and as a result had a large degree of uncertainty in relation to the potential for recurrence or progression. The FearLESS program was a stratified version of stepped care where those survivors who scored in the normal range received treatment as usual. Those scoring in the sub-clinical range for FCR were directed to a self-help intervention, supported with phone calls and screened again five weeks later. In contrast, those who scored in the clinical range for FCR were provided with individualised therapy sessions based on ConquerFear. ${ }^{26}$ The FearLESS model holds some promise, as the results showed that participants engaged with the intervention offered and the majority of those assigned to self-help indicated that they did not want further intervention (90\%). Although 13 of the 21 completers in the self-help condition reported numerical decreases in their FCR scores, the effect size was very small (Cohen's $d=0.11) .{ }^{56}$ The individual therapy resulted in larger changes (Cohen's $d=0.7$ ), which were similar to the within-group effects in the ConquerFear trial, suggesting that the approach is likely suited to more advanced patients. Nevertheless, this was a study with a high risk of bias given the absence of a control group, and the absence of evidence-based minimal interventions makes the provision of effective stepped care approaches challenging.

In order to develop an effective stepped care approach, or to determine the nature of a stepped care approach that might be most suited to FCR, we need more research. If a brief oncologist delivered intervention at the end of treatment, such as that developed by Liu et $\mathrm{al}^{32}$ was to prove efficacious in RCTs, this would potentially be an easily delivered universal step. That is, an oncologist-based intervention could be incorporated into routine care of all survivors with the hope of preventing clinically significant levels of FCR. Currently, we desperately need to evaluate the available internet-delivered minimal interventions specific to FCR which could then be used as a second step in the stepped care program. We have effective individual face-to-face interventions that produce modest changes in FCR/P. There are few moderation studies of who benefits most, but we know that the relative benefit of ConquerFear was greater for those with higher baseline levels of FCR. ${ }^{57}$ This would suggest that a matched approach to stepped care might be most useful. However, it would be important to demonstrate that those with higher FCR/P did not also benefit most from minimal interventions.

One could envisage a model of stepped care, where on a first, universal step, oncologists were encouraged to normalise $\mathrm{FCR} / \mathrm{P}$, provide reassurance and accurate prognostic information, as well as specifying the likely symptoms associated with FCR/P to all their patients (eg, Liu et al; ${ }^{30}$ See Figure 1). Survivors might then be screened at routine

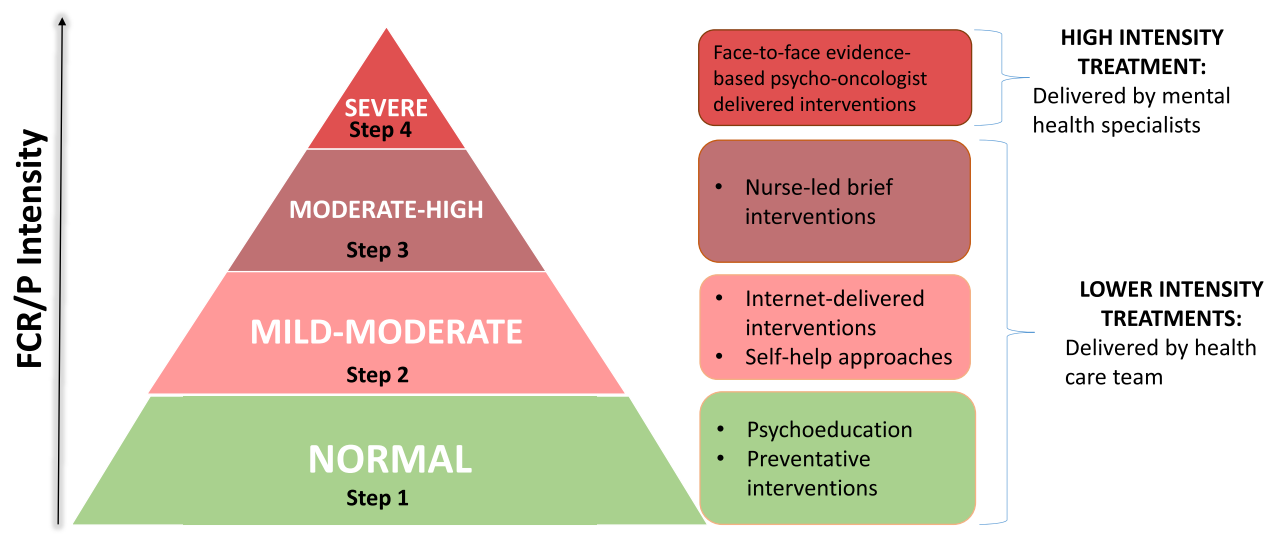

Figure I Stepped care model to fear of cancer recurrence/progression in oncology services. 
follow-up appointments. Those who developed a "sub" clinical level of symptoms might be encouraged to engage with an efficacious minimal intervention, while those with moderate symptoms might be referred for brief nurse-led interventions. This would reserve specialist psycho-oncologists to work with those survivors with the most severe levels of FCR/P. However, we should also be investigating ways to improve the outcome of existing treatments, which continue to leave a large proportion of survivors in the sub-clinical and clinical range for FCR/P.

\section{Maximising Existing Interventions}

Although existing face-to-face interventions are effective, the effect sizes of treatments are small, on average, and the majority of participants still score in at least the sub-clinical range following treatment (e.g. ${ }^{26,28}$ ). Future research should focus on how to further improve outcomes for survivors with severe FCR and for those with advanced disease (refer to Table 2 for recommendations for future research). There are a number of ways in which to address the problem of finding more efficacious treatments. Firstly, one can examine mediators of treatments that work, which can indicate the likely treatment mechanism and increase the focus on intervention strategies that target those factors. For example, changes in metacognitions and intrusions were found to moderate the relative efficacy of ConquerFear versus relaxation training. ${ }^{57}$ Hence, focusing more on metacognitive therapy, ${ }^{20}$ or interventions (such as the worst case scenario ${ }^{58}$ ) may increase the efficacy of existing approaches. Secondly, it is possible that if both traditional and contemporary CBT approaches are both

Table 2 Recommendations to Guide Future Research

\begin{tabular}{|l|}
\hline Recommendations for Future Research \\
\hline $\begin{array}{l}\text { I. Development and evaluation of universal minimal interventions (eg } \\
\text { clinician-delivered, psychoeducational interventions, informational } \\
\text { resources, apps) designed to help prevent FCR. }\end{array}$ \\
\hline $\begin{array}{l}\text { 2. Development and evaluation of minimal interventions (eg internet- } \\
\text { delivered treatments) that are targeted for those with mild to } \\
\text { moderate FCR }\end{array}$ \\
\hline $\begin{array}{l}\text { 3. Up-skilling oncology professionals to deliver interventions targeting } \\
\text { FCR in routine clinical practice. }\end{array}$ \\
\hline 4. Research to improve existing interventions for severe FCR. \\
\hline $\begin{array}{l}\text { 5.Adapting available evidence-based FCR interventions for those with } \\
\text { advanced disease. }\end{array}$ \\
\hline $\begin{array}{l}\text { 6. Testing models of stepped care to develop the most efficacious and } \\
\text { highly implementable service model. }\end{array}$ \\
\hline
\end{tabular}

effective, that together they might be more efficacious. A recent case series of a combined approach for transdiagnostic anxiety (including FCR/P) showed that $65 \%$ of patients with advanced disease no longer scored in the clinical range following treatment, ${ }^{59}$ but again as a case series this study is at risk of bias. Finally, theoretical models can be used to guide the development of improved interventions, such as focusing on modifying interpretation biases, argued to drive FCR in the threat interpretation model ${ }^{60}$ or focusing on death anxiety ${ }^{61}$ which is seen as central in Simonelli et al's ${ }^{62}$ model of FCR. While improving treatments will require more research, the existence of moderately effective psychological treatments should be seen as a starting point for further improving approaches to manage FCR.

There is no doubt that over the past ten years, numerous efficacious psychological treatments for FCR/P have been developed and evaluated. However, these are associated with small to moderate effects with most survivors who complete treatment remaining in either the clinical or sub-clinical range. It may be that combining efficacious treatments, targeting factors that are associated with FCR or increasing the dose of effective treatment components would result in larger improvements. However, research is needed to determine this. Despite a range of efficacious treatments, there is simply not the workforce available to make these treatments available to all survivors with moderate to severe FCR. Furthermore, based on the past literature, we still do not have evidence-based interventions to be able to implement a stepped care approach for FCR. Therefore, we desperately need evidence-based minimal interventions that can be developed for use as part of a stepped care model, as well as good preventative approaches, to meet the needs of the growing number of cancer survivors who fear recurrence or progression.

\section{Disclosure}

The authors report no conflicts of interest in this work.

\section{References}

1. Allemani C, Matsuda T, Di Carlo V, et al. Global surveillance of trends in cancer survival 2000-14 (Concord-3): analysis of individual records for 37513025 patients diagnosed with one of 18 cancers from 322 population-based registries in 71 countries. Lancet. 2018;391 (10125):1023-1075. doi:10.1016/s0140-6736(17)33326-3

2. Simard S, Savard J. Fear of cancer recurrence inventory: development and initial validation of a multidimensional measure of fear of cancer recurrence. Support Care Cancer. 2009;17(3):241-251. doi:10.1007/ s00520-008-0444-y

3. Kim Y, Carver CS, Spillers RL, Love-Ghaffari M, Kaw C-K. Dyadic effects of fear of recurrence on the quality of life of cancer survivors and their caregivers. Qual Life Res. 2012;21(3):517-525. doi:10.1007/ s11136-011-9953-0 
4. van den Beuken-van Everdingen MHJ, Peters ML, de Rijke JM, Schouten HC, van Kleef M, Patijn J. Concerns of former breast cancer patients about disease recurrence: a validation and prevalence study. Psycho Oncol. 2008;17(11):1137-1145. doi:10.1002/pon.1340

5. Simard S, Thewes B, Humphris G, et al. Fear of cancer recurrence in adult cancer survivors: a systematic review of quantitative studies. J Cancer Surviv. 2013;7(3):300-322. doi:10.1007/s11764-013-0272-z

6. Lebel S, Ozakinci G, Humphris G, et al. From normal response to clinical problem: definition and clinical features of fear of cancer recurrence. Support Care Cancer. 2016;24(8):3265-3268. doi:10.1007/s00520-016-3272-5

7. Fardell J, Thewes B, Turner J, et al. Fear of cancer recurrence: a theoretical review and novel cognitive processing formulation. $J$ Cancer Survivorsh. 2016;10(4):663-673. doi:10.1007/s11764-0150512-5

8. Wang HH, Chung UL. Healthy lifestyle changes during the period before and after cancer diagnosis among breast cancer survivors. Asian Pacific J Cancer Prev. 2012;13(9):4769-4772. doi:10.7314/ apjcp.2012.13.9.4769

9. Mehnert A, Koch U, Sundermann C, Dinkel A. Predictors of fear of recurrence in patients one year after cancer rehabilitation: a prospective study. Acta Oncol. 2013;52(6):1102-1109. doi:10.3109/0284186x.2013.765063

10. Koch L, Bertram H, Eberle A, et al. Fear of recurrence in long-term breast cancer survivors-still an issue. Results on prevalence, determinants, and the association with quality of life and depression from the cancer survivorship - a multi-regional population-based study. Psycho Oncol. 2013;23(5):547-554. doi:10.1002/pon.3452

11. Mutsaers B, Butow P, Dinkel A, et al. Identifying the key characteristics of clinical fear of cancer recurrence: an international Delphi study. Psychooncology. 2020;29(2):430-436. doi:10.1002/pon.5283

12. Lebel S, Tomei C, Feldstain A, Beattie S, McCallum M. Does fear of cancer recurrence predict cancer survivors' health care use? Support Care Cancer. 2013;21(3):901-906. doi:10.1007/s00520-012-1685-3

13. Thewes B, Butow P, Bell ML, et al. Fear of cancer recurrence in young women with a history of early-stage breast cancer: a cross-sectional study of prevalence and association with health behaviours. Support Care Cancer. 2012;20(11):2651-2659. doi:10.1007/s00520-011-1371-x

14. Williams JT, Pearce A, Smith AB. A systematic review of fear of cancer recurrence related healthcare use and intervention cost-effectiveness. Psycho Oncol. 2021;30(8):1185-1195. doi:10.1002/ pon. 5673

15. Humphris GM, Rogers S, McNally D, Lee-Jones C, Brown J, Vaughan D. Fear of recurrence and possible cases of anxiety and depression in orofacial cancer patients. Int J Oral Maxillofac Surg. 2003;32(5):486-491. doi:10.1016/s0901-5027(03)90399-1

16. Koch L, Jansen L, Brenner H, Arndt V. Fear of recurrence and disease progression in long-term ( $\geq 5$ years) cancer survivors-a systematic review of quantitative studies. Psycho Oncol. 2013;22 (1):1-11. doi:10.1002/pon.3022

17. Mehnert A, Berg P, Henrich G, Herschbach P. Fear of cancer progression and cancer-related intrusive cognitions in breast cancer survivors. Psychooncology. 2009;18(12):1273-1280. doi:10.1002/ pon. 1481

18. Butow P, Sharpe L, Thewes B, Turner J, Gilchrist J, Beith J. Fear of cancer recurrence: a practical guide for clinicians. Oncology (Williston Park). 2018;32(1):32-38.

19. Thewes B, Brebach R, Dzidowska M, Rhodes P, Sharpe L, Butow P. Current approaches to managing fear of cancer recurrence; a descriptive survey of psychosocial and clinical health professionals. Psycho Oncol. 2014;23(4):390-396. doi:10.1002/ pon. 3423

20. Fisher P, Byrne A, Salmon P. Metacognitive therapy for emotional distress in adult cancer survivors: a case series. Cognit Ther Res. 2017;41(6):891-901. doi:10.1007/s10608-017-9862-9
21. Heinrichs N, Zimmermann T, Huber B, Herschbach P, Russell DW, Baucom DH. Cancer distress reduction with a couple-based skills training: a randomized controlled trial. Ann Behav Med. 2012;43 (2):239-252. doi:10.1007/s12160-011-9314-9

22. Lengacher CA, Johnson-Mallard V, Post-White J, et al. Randomized controlled trial of mindfulness-based stress reduction (MBSR) for survivors of breast cancer. Psychooncology. 2009;18 (12):1261-1272. doi:10.1002/pon.1529

23. Lee-Jones C, Humphris G, Dixon R, Bebbington Hatcher M. Fear of cancer recurrence - a literature review and proposed cognitive formulation to explain exacerbation of recurrence fears. Psycho Oncol. 1997;6(2):95-105. doi:10.1002/(sici)1099-1611(199706)6:2<95::aidpon $250>3.0 . c o ; 2-b$

24. Herschbach P, Book K, Dinkel A, et al. Evaluation of two group therapies to reduce fear of progression in cancer patients. Support Care Cancer. 2010;18(4):471-479. doi:10.1007/s00520-009-0696-1

25. Humphris G, Rogers SN. AFTER and beyond: cancer recurrence fears and a test of an intervention in oral and oropharyngeal patients. Soc Sci Dent. 2012;2(1):29-38.

26. Butow P, Turner J, Gilchrist J, et al. Randomized trial of conquerfear: a novel, theoretically based psychosocial intervention for fear of cancer recurrence. J Clin Oncol. 2017;35(36):4066-4077. doi:10.1200/jco.2017.73.1257

27. Tauber NM, O'Toole MS, Dinkel A, et al. Effect of psychological intervention on fear of cancer recurrence: a systematic review and meta-analysis. JCO. 2019;37(31):2899-2915. doi:10.1200/ jco. 19.00572

28. van de Wal M, Thewes B, Gielissen M, Speckens A, Prins J. Efficacy of blended cognitive behavior therapy for high fear of recurrence in breast, prostate, and colorectal cancer survivors: the SWORD study, a randomized controlled trial. JCO. 2017;35(19):2173-2183. doi:10.1200/jco.2016.70.5301

29. Thewes B, Husson O, Poort H, et al. Fear of cancer recurrence in an era of personalized medicine. JCO. 2017;35(29):3275-3278. doi:10.1200/jco.2017.72.8212

30. Liu JJ, Butow P, Beith J. Systematic review of interventions by non-mental health specialists for managing fear of cancer recurrence in adult cancer survivors. Support Care Cancer. 2019;27 (11):4055-4067. doi:10.1007/s00520-019-04979-8

31. Shields CG, Ziner KW, Bourff SA, et al. An intervention to improve communication between breast cancer survivors and their physicians. J Psychosoc Oncol. 2010;28(6):610-629. doi:10.1080/ 07347332.2010 .516811

32. Liu J, Butow P, Bui KT, et al. Novel clinician-lead intervention to address fear of cancer recurrence in breast cancer survivors. JCO Oncol Pract. 2021;17(6):e774-e784. doi:10.1200/op.20.00799

33. Reb A, Borneman T, Economou D, Cangin M, Patel S, Sharpe L. Fear of cancer progression: findings from case studies and a nurse-led intervention. CJON. 2020;24(4):400-408. doi:10.1188/20.cjon.400-408

34. Reb AM, Borneman T, Economou D, et al. A nurse-led intervention for fear of cancer progression in advanced cancer: a pilot feasibility study. Eur J Oncol Nurs. 2020;49:101855. doi:10.1016/j. ejon.2020.101855

35. Brebach R, Sharpe L, Costa D, Rhodes P, Butow P. Psychological intervention targeting distress for cancer patients: a meta-analytic study investigating uptake and adherence. Psychooncology. 2016;25 (8):882-890. doi:10.1002/pon.4099

36. Glasgow RE, Fisher L, Strycker LA, et al. Minimal intervention needed for change: definition, use, and value for improving health and health research. Transl Behav Med. 2013;4(1):26-33. doi:10.1007/s13142-013-0232-1

37. Cuthbert C, Farragher J, Hemmelgarn B, Ding Q, McKinnon G, Cheung W. Self-management interventions for cancer survivors: a systematic review and evaluation of intervention content and theories. Psychooncology. 2019;28(11):2119-2140. doi:10.1002/ pon.5215 
38. Pradhan P, Sharpe L, Butow PN, Smith AB, Russell H. Is a brief online booklet sufficient to reduce fear of cancer recurrence or progression in women with ovarian cancer? Front Psychol. 2021;12:634136. doi:10.3389/fpsyg.2021.634136

39. Omidi Z, Kheirkhah M, Abolghasemi J, Haghighat S. Effect of lymphedema self-management group-based education compared with social network-based education on quality of life and fear of cancer recurrence in women with breast cancer: a randomized controlled clinical trial. Qual Life Res. 2020;29(7):1789. doi:10.1007/ s11136-020-02455-z

40. Dieng M, Butow P, Costa D, et al. Psychoeducational intervention to reduce fear of cancer recurrence in people at high risk of developing another primary melanoma: results of a randomized controlled trial. J Clin Oncol. 2016;34(36):4405-4414. doi:10.1200/jco.2016.68.2278

41. Dieng M, Khanna N, Kasparian N, et al. Cost-effectiveness of a psycho-educational intervention targeting fear of cancer recurrence in people treated for early-stage melanoma. Appl Health Econ Health Policy. 2019;17(5):669-681. doi:10.1007/s40258-019-00483-6

42. Otto AK, Szczesny EC, Soriano EC, Laurenceau J-P, Siegel SD. Effects of a randomized gratitude intervention on death-related fear of recurrence in breast cancer survivors. Health Psychol. 2016;35 (12):1320-1328. doi:10.1037/hea0000400

43. Lichtenthal WG, Corner GW, Slivjak ET, et al. A pilot randomized controlled trial of cognitive bias modification to reduce fear of breast cancer recurrence: fear of cancer recurrence intervention. Cancer. 2017;123(8):1424-1433. doi:10.1002/cncr.30478

44. Beard C. Cognitive bias modification for anxiety: current evidence and future directions. Expert Rev Neurother. 2011;11(2):299-311. doi:10.1586/ern.10.194

45. Barak A, Hen L, Boniel-Nissim M, Shapira N. A comprehensive review and a meta-analysis of the effectiveness of internet-based psychotherapeutic interventions. J Technol Hum Serv. 2008;26(24):109-160. doi:10.1080/15228830802094429

46. Gainsbury S, Blaszczynski A. A systematic review of Internet-based therapy for the treatment of addictions. Clin Psychol Rev. 2011;31 (3):490-498. doi:10.1016/j.cpr.2010.11.007

47. Andersson G, Cuijpers P. Internet-based and other computerized psychological treatments for adult depression: a meta-analysis. Cogn Behav Ther. 2009;38(4):196-205. doi:10.1080/16506070903318960

48. Karyotaki E, Ebert DD, Donkin L, et al. Do guided internet-based interventions result in clinically relevant changes for patients with depression? An individual participant data meta-analysis. Clin Psychol Rev. 2018;63:80-92. doi:10.1016/j.cpr.2018.06.007

49. van Helmondt SJ, Lee ML, Woezik RAM, Lodder P, Vries J. No effect of CBT-based online self-help training to reduce fear of cancer recurrence: first results of the CAREST multicenter randomized controlled trial. Psycho Oncol. 2020;29(1):86-97. doi:10.1002/pon.5233

50. Smith A, Bamgboje-Ayodele A, Butow P, et al. Development and usability evaluation of an online self-management intervention for fear of cancer recurrence (iConquerFear). Psycho Oncol. 2019;29 (1):98-106. doi:10.1002/pon.5218

51. Lyhne JD, Smith A' B, Frostholm L, Fink P, Jensen LH. Study protocol: a randomized controlled trial comparing the efficacy of therapist guided internet-delivered cognitive therapy (TG-iConquerFear) with augmented treatment as usual in reducing fear of cancer recurrence in Danish colorectal cancer survivors. BMC Cancer. 2020;20(1):223. doi:10.1186/s12885-020-06731-6

52. Akechi T, Yamaguchi $T$, Uchida $M$, et al. Smartphone problem-solving and behavioural activation therapy to reduce fear of recurrence among patients with breast cancer (SMartphone Intervention to LEssen fear of cancer recurrence: SMILE project): protocol for a randomised controlled trial. BMJ Open. 2018;8(11): e024794. doi:10.1136/bmjopen-2018-024794
53. Wagner LI, Duffecy J, Penedo F, Mohr DC, Cella D. Coping strategies tailored to the management of fear of recurrence and adaptation for E-health delivery: the FoRtitude intervention. Cancer. 2017;123 (6):906-910. doi: $10.1002 / \mathrm{cncr} .30602$

54. Dirkse D, Hadjistavropoulos H, Alberts N, et al. Making Internet-delivered cognitive behaviour therapy scalable for cancer survivors: a randomized non-inferiority trial of self-guided and technician-guided therapy. $J$ Cancer Survivorsh. 2019;14 (2):211-225. doi:10.1007/s11764-019-00810-9

55. Linton SJ, Nicholas M, Shaw W. Why wait to address high-risk cases of acute low back pain? A comparison of stepped, stratified, and matched care. Pain. 2018;159(12):2437-2441. doi:10.1097/j. pain. 0000000000001308

56. Lynch FA, Katona L, Jefford M, et al. Feasibility and acceptability of fear-less: a stepped-care program to manage fear of cancer recurrence in people with metastatic melanoma. J Clin Med. 2020;9(9):2969. doi: $10.3390 /$ j $\mathrm{cm} 9092969$

57. Sharpe L, Turner J, Fardell JE, et al. Psychological intervention (conquerfear) for treating fear of cancer recurrence: mediators and moderators of treatment efficacy. $J$ Cancer Surviv. 2019;13 (5):695-702. doi:10.1007/s11764-019-00788-4

58. Moran C, Tomei C, Lefebvre M, Harris C, Maheu C, Lebel S. An exploratory study of the worst-case scenario exercise as an exposure treatment for fear of cancer recurrence. Support Care Cancer. 2017;25(5):1373-1375. doi:10.1007/s00520-017-3600-4

59. Curran L, Sharpe L, Butow P. Pilot of a novel theoretically derived intervention for cancer-related anxiety with patients with advanced or recurred disease. Behav Cogn Psychother. 2021;49(2):247-253. doi:10.1017/s1352465820000697

60. Heathcote LC, Eccleston C. Pain and cancer survival. Pain. 2017;158 (7):1187-1191. doi:10.1097/j.pain.0000000000000872

61. Sharpe L, Curran L, Butow P, Thewes B. Fear of cancer recurrence and death anxiety. Psycho Oncol. 2018;27(11):2559-2565. doi:10.1002/pon.4783

62. Simonelli LE, Siegel SD, Duffy NM. Fear of cancer recurrence: a theoretical review and its relevance for clinical presentation and management. Psycho Oncol. 2016;26(10):1444-1454. doi:10.1002/ pon. 4168

63. Arch JJ, Mitchell JL. An Acceptance and Commitment Therapy (ACT) group intervention for cancer survivors experiencing anxiety at re-entry. Psycho Oncol. 2015;25(5):610-615. doi:10.1002/ pon. 3890

64. Bannaasan B, Pothiban L, Khampolsiri T, Saengthong S. Effects of Buddhist doctrine-based practice on fear of cancer recurrence and hopelessness: a randomized controlled trial. Pac Rim Int J Nurs Res Thail. 2015;19(4):295-310.

65. Bower JE, Crosswell AD, Stanton AL, et al. Mindfulness meditation for younger breast cancer survivors: a randomized controlled trial. Cancer. 2014;121(8):1231-1240. doi:10.1002/cncr.29194

66. Cameron LD, Booth RJ, Schlatter M, Ziginskas D, Harman JE. Changes in emotion regulation and psychological adjustment following use of a group psychosocial support program for women recently diagnosed with breast cancer. Psycho Oncol. 2007;16(3):171-180. doi:10.1002/pon. 1050

67. Chambers SK, Foley E, Galt E, Ferguson M, Clutton S. Mindfulness groups for men with advanced prostate cancer: a pilot study to assess feasibility and effectiveness and the role of peer support. Support Care Cancer. 2011;20(6):1183-1192. doi:10.1007/s00520-011-1195-8

68. Crane-Okada R, Kiger H, Sugerman F, et al. Mindful movement program for older breast cancer survivors. Cancer Nurs. 2012;35 (4):E1-E13. doi:10.1097/ncc.0b013e3182280f73

69. Davidson J, Malloch M, Humphris G. A single-session intervention (the Mini-AFTERc) for fear of cancer recurrence: a feasibility study. Psycho Oncol. 2018;27(11):2668-2670. doi:10.1002/pon.4724 
70. Dodds SE, Pace TWW, Bell ML, et al. Feasibility of Cognitively-Based Compassion Training (CBCT) for breast cancer survivors: a randomized, wait list controlled pilot study. Support Care Cancer. 2015;23(12):3599-3608. doi:10.1007/s00520-015-2888-1

71. Germino BB, Mishel MH, Crandell J, et al. Outcomes of an uncertainty management intervention in younger African American and Caucasian breast cancer survivors. Oncol Nurs Forum. 2012;40 (1):82-92. doi:10.1188/13.onf.82-92

72. Gonzalez-Hernandez E, Romero R, Campos D, et al. CognitivelyBased Compassion Training $\left(\mathrm{CBCT}^{\circledR}\right)$ in breast cancer survivors: a randomized clinical trial study. Integr Cancer Ther. 2018;17 (3):684-696. doi:10.1177/1534735418772095

73. Johns SA, Stutz PV, Talib TL, et al. Acceptance and commitment therapy for breast cancer survivors with fear of cancer recurrence: a 3-arm pilot randomized controlled trial. Cancer. 2020;126 (1):211-218. doi:10.1002/cncr.32518

74. Lebel S, Maheu C, Lefebvre M, et al. Addressing fear of cancer recurrence among women with cancer: a feasibility and preliminary outcome study. J Cancer Surviv. 2014;8(3):485-496. doi:10.1007/ s11764-014-0357-3

75. Lengacher CA, Reich RR, Paterson CL, et al. Examination of broad symptom improvement resulting from mindfulness-based stress reduction in breast cancer survivors: a randomized controlled trial. JCO. 2016;34(24):2827-2834. doi:10.1200/jco.2015.65.7874

76. Lengacher CA, Reich RR, Ramesar S, et al. Feasibility of the mobile mindfulness-based stress reduction for breast cancer (mMBSR(BC)) program for symptom improvement among breast cancer survivors. Psycho Oncol. 2018;27(2):524-531. doi:10.1002/pon.4491

77. Manne SL, Virtue SM, Ozga M, et al. A comparison of two psychological interventions for newly-diagnosed gynecological cancer patients. Gynecol Oncol. 2017;144(2):354-362. doi:10.1016/j. ygyno.2016.11.025

78. Merckaert I, Lewis F, Delevallez F, et al. Improving anxiety regulation in patients with breast cancer at the beginning of the survivorship period: a randomized clinical trial comparing the benefits of single-component and multiple-component group interventions. Psycho Oncol. 2017;26(8):1147-1154. doi:10.1002/pon.4294
79. Momino K, Mitsunori M, Yamashita H, et al. Collaborative care intervention for the perceived care needs of women with breast cancer undergoing adjuvant therapy after surgery: a feasibility study. Jpn J Clin Oncol. 2017;47(3):213-220. doi:10.1093/jjco/hyw189

80. Savard J, Savard M-H, Caplette-Gingras A, Casault L, Camateros C. Development and feasibility of a group cognitive-behavioral therapy for fear of cancer recurrence. Cogn Behav Pract. 2018;25 (2):275-285. doi:10.1016/j.cbpra.2017.08.001

81. Seitz DCM, Knaevelsrud C, Duran G, Waadt S, Loos S, Goldbeck L. Efficacy of an internet-based cognitive-behavioral intervention for long-term survivors of pediatric cancer: a pilot study. Support Care Cancer. 2014;22(8):2075-2083. doi:10.1007/s00520-014-2193-4

82. Smith A, Thewes B, Turner J, et al. Pilot of a theoretically grounded psychologist-delivered intervention for fear of cancer recurrence (Conquer Fear). Psycho Oncol. 2015;24(8):967-970. doi:10.1002/pon.3775

83. Sterba KR, Armeson K, Franco R, et al. A pilot randomized controlled trial testing a minimal intervention to prepare breast cancer survivors for recovery. Cancer Nurs. 2015;38(2):E48-E56. doi:10.1097/ncc.0000000000000152

84. Tomei C, Lebel S, Maheu C, Lefebvre M, Harris C. Examining the preliminary efficacy of an intervention for fear of cancer recurrence in female cancer survivors: a randomized controlled clinical trial pilot study. Support Care Cancer. 2018;26(8):2751-2762. doi:10.1007/s00520-0184097-1

85. Victorson D, Hankin V, Burns J, et al. Feasibility, acceptability and preliminary psychological benefits of mindfulness meditation training in a sample of men diagnosed with prostate cancer on active surveillance: results from a randomized controlled pilot trial. Psycho Oncol. 2017;26(8):1155-1163. doi:10.1002/pon.4135

\section{Publish your work in this journal}

Cancer Management and Research is an international, peer-reviewed open access journal focusing on cancer research and the optimal use of preventative and integrated treatment interventions to achieve improved outcomes, enhanced survival and quality of life for the cancer patient.
The manuscript management system is completely online and includes a very quick and fair peer-review system, which is all easy to use. Visit http://www.dovepress.com/testimonials.php to read real quotes from published authors. 